\title{
Citotoxicity and Immune Response induced by Organopalladium(II) Compounds in Mice bearing Ehrlich Ascites Tumour
}

\author{
Michelle C. da Rocha, ${ }^{a}$ Anderson M. Santana, ${ }^{b}$ Sandra R. Ananias, ${ }^{a, b}$ Eduardo T. de Almeida, ${ }^{c}$ \\ Antonio E. Mauro, ${ }^{b}$ Marisa C. P. Placeres ${ }^{a}$ and Iracilda Z. Carlos ${ }^{a, *}$ \\ ${ }^{a}$ Departamento de Análises Clínicas, Faculdade de Ciências Farmacêuticas de Araraquara, \\ Universidade Estadual Paulista, CP 502, 14801-902 Araraquara-SP, Brazil \\ ${ }^{b}$ Departamento de Química Geral e Inorgânica, Instituto de Química de Araraquara, \\ Universidade Estadual Paulista, CP 355, 14801-970 Araraquara-SP, Brazil \\ ${ }^{c}$ Departamento de Ciências Exatas, Universidade Federal de Alfenas, 31130-000 Alfenas-MG, Brazil
}

Os ciclometalados de paládio(II) são compostos inorgânicos reativos empregados em vários estudos biológicos devido a seu potencial antitumoral e interação com o sistema imune. Neste estudo, a resposta imune e citotóxica induzida por dois complexos organopaladados: $\left[\{\mathrm{Pd}(N, C \text {-dmba })\}_{2}(\mu-N C S)_{2}\right](1),[\mathrm{Pd}(C$-dmba $)(\mathrm{NCS})(\mathrm{dppp})](2)[\mathrm{dmba}$ $=N, N^{\prime}$-dimetilbenzilamina, $\mathrm{dppp}=1,3$-bis(difenilfosfino)propano] e cisplatina (cis-DDP), como padrão, foram investigados em camundongos portadores do tumor ascítico de Ehrlich. Os camundongos foram divididos em cinco grupos e inoculados com (1) ou (2) ou cis-DDP ou apenas veículo ou solução salina tamponada de fosfatos (PBS). Diversos parâmetros foram avaliados, tais como a porcentagem de células tumorais presentes no exsudato peritoneal, os níveis de óxido nítrico (NO) e fator de necrose tumoral (TNF- $\alpha$ ) séricos e o aumento na expectativa de vida. Os dados obtidos demonstram que o composto (2) apresentou atividade similar à da cis-DDP, como, por exemplo, aumento na expectativa de vida, diminuição dos níveis séricos de TNF- $\alpha$ e aumento da produção de NO.

Cyclometallated palladium(II) complexes are reactive inorganic compounds employed in several biological studies because of their antitumour potential and interaction with immune system. In the present study, the immune and citotoxic response induced by two organopalladated complexes: $\left[\left\{\mathrm{Pd}(N, C \text {-dmba }\}_{2}(\mu-\mathrm{NCS})_{2}\right](\mathbf{1}),[\mathrm{Pd}(C\right.$-dmba)(NCS $)(\mathrm{dppp})](2)\left[\mathrm{dmba}=N, N^{\prime}-\right.$ dimethylbenzylamine, dppp $=1,3$-bis(diphenylphosphino)propane] and cisplatin (cis-DDP), as standard, were investigated in mice bearing Ehrlich ascites tumour. The mice were divided into five groups and inoculated with the compounds (1) or (2) or cisplatin, or only vehicle or phosphatebuffered saline (PBS). Many parameters were evaluated, such as tumour cell percentage in the peritoneal exsudate, levels of seric nitric oxide (NO) and tumour necrosis factor-alpha (TNF- $\alpha$ ) and increase in life span. Analysis of all data revealed, for compound (2), an activity similar to that presented by cisplatin, resulting in increased life span, lower levels of seric TNF- $\alpha$ and increase in NO production.

Keywords: palladium(II) complexes, Ehrlich ascites tumour, macrophages, nitric oxide, tumour necrosis factor-alpha.

\section{Introduction}

Cancer is a disease in which unremitting clonal expansion of somatic cells kills by invading, subverting, and eroding normal tissues. ${ }^{1}$ Millions of people die every year from the metastatic spread of cancer that occurs

*e-mail: carlosiz@fcfar.unesp.br through blood and lymphatic vessels or directly into tissues and body cavities. ${ }^{2}$ Between the several types of cancer, breast cancer is the most common malignancy in women worldwide. $^{3}$

In some cases, immune cells constitute a prominent component of the host response to cancer, but their participation in tumour pathogenesis remains not completely understood. Dense intratumoral lymphocyte 
infiltrates in early stages of neoplasm are strongly related with reduced frequencies of metastasis and improved survival time of patients with several types of cancer. ${ }^{4}$ Macrophages play an important role in the host defence against the neoplastic disease, recognizing and killing tumour cells, which are activated with a variety of agents and produce a number of citostatic or citotoxic mediators upon stimulation. ${ }^{5}$ This process involves the release of reactive oxygen intermediates (ROI) during the respiratory burst, along with reactive nitrogen intermediates (RNI) and proinflammatory cytokines like tumour necrosis factor (TNF). ${ }^{6}$ When these inflammatory mediators are produced in high quantities, they mediate the tissue damage associated with inflammation and ischemic injury. ${ }^{7,8}$

cis-Diamminedichloroplatinum(II), ${ }^{9}$ a clinically important antitumour drug, acts like a classical alkylating agent in chemotherapy against some types of cancers. It is a potent stimulator of macrophages and polimorphonuclear leukocytes in the human body. This drug has been proved to be effective alone or in addition to other drugs or cytokines for the treatment of a variety of human and animal malignancies, ${ }^{10}$ but its administration in humans shows many side effects such as nausea, nephrotoxicity and neurotoxicity. ${ }^{11}$ In addition, its applicability is still limited to a relatively few number of tumours. This effect occurs because of the natural resistance to cisplatin or because of the resistance that happens after the initial treatment. These drawbacks are a strong reason for the development of new metal drugs containing other metal centres, for instance, cyclopalladated complexes, which in a previous research presented citotoxic potential in tests in vitro against several tumour lineages. ${ }^{12}$ However, currently in vivo investigations are very scarce, mainly evaluating effects of organopalladium solutions in cell viability and their ability to induce murine macrophages to recognize and to attack tumour cells.

As part of a program directed at the synthesis of complexes having ligands with noteworthy biological properties, such as aromatic amines and diphenylphosphines, the present research evaluated the citotoxic activity of the organopalladated compounds $\left[\{\mathrm{Pd}(\mathrm{dmba})\}_{2}(\mu-\mathrm{NCS})_{2}\right](\mathbf{1})$ and $[\mathrm{Pd}(\mathrm{dmba})(\mathrm{NCS})(\mathrm{dppp})]$ (2), dmba $=N, N^{\prime}$ - dimethylbenzylamine, dppp $=1,3-$ bis(diphenylphosphino)propane, Figure 1, against Ehrlich ascites tumour (EAT), evaluating their citotoxic potential in vitro $\left(\mathrm{IC}_{50}\right)$, besides their effects in the inflammatory response, the mean survival time and the increase in life span of groups of Swiss mice. In all experiments, cis-diamminedichloroplatinum(II) (cisDDP) was used as a standard drug.

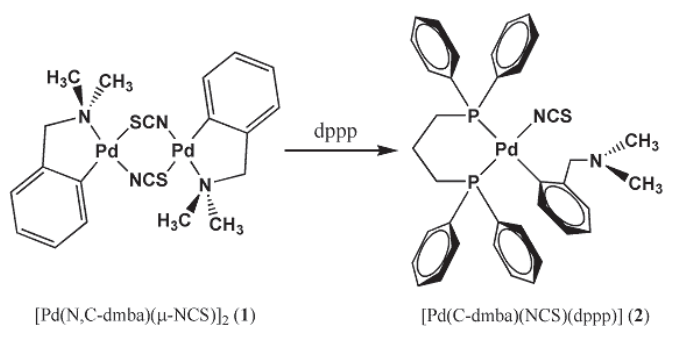

Figure 1. Structures of cyclopalladated compounds $\left[\{\operatorname{Pd}(N, C-d m b a)\}_{2}\right.$ $\left.(\mu-\mathrm{X})_{2}\right](\mathbf{1})$ and $[\mathrm{Pd}(C-\mathrm{dmba})(\mathrm{X})(\mathrm{dppp})](\mathbf{2}), \mathrm{X}=\mathrm{NCS}$.

\section{Experimental}

\section{Synthesis}

All the syntheses were carried out at room temperature and the reagents were employed without further purification.

The compound $\left[\{\mathrm{Pd}(\mathrm{N}, \mathrm{C}-\mathrm{dmba})\}_{2}(\mu-\mathrm{NCS})_{2}\right](\mathbf{1})$ was obtained and characterized according to literature methods. ${ }^{13}$ The $[\mathrm{Pd}(\mathrm{C}$-dmba)(NCS)(dppp)] (2) was obtained as described: to a yellow suspension of 250 $\mathrm{mg}(0.42 \mathrm{mmol})$ of $\left[\{\mathrm{Pd}(\mathrm{N}, \mathrm{C}-\mathrm{dmba})\}_{2}(\mu-\mathrm{NCS})_{2}\right](\mathbf{1})$ in $30 \mathrm{~mL}$ of acetone, $71.90 \mathrm{mg}(0.84 \mathrm{mmol})$ of $1,3-$ bis(diphenylphosphino)propane (dppp) were added. The resulting solution was stirred for $1 \mathrm{~h}$ and then concentrated under reduced pressure. Addition of dichloromethane and pentane gave a white solid. The solid was filtered off, washed thoroughly with pentane and dried in vacuo. Yield: $90 \%$ (Found: $\mathrm{C}, 62.25 ; \mathrm{H}$, 5.78; N, 4.06; S, 4.32. Calc. for $\mathrm{C}_{37} \mathrm{H}_{36} \mathrm{~N}_{2} \mathrm{SP}_{2} \mathrm{Pd}$ : C, 62.40; H, 5.52; N, 3.93; S, 4.50\%).

We have employed commercial cisplatin Fauldiscipla ${ }^{\circledR}$ $1 \mathrm{mg} \mathrm{mL} \mathrm{m}^{-1}$ in this investigation as standard.

\section{Instrumental}

IR spectra were recorded on a NICOLET IMPACT 400 spectrophotometer in the $4000-400 \mathrm{~cm}^{-1}$ range with the samples in the form of $\mathrm{KBr}$ pellets.

\section{Tumour cell line}

The tumour cell line used in this experiment was Ehrlich ascites tumour (EAT). The maintenance of tumour was made according to literature methods. ${ }^{14}$ This procedure was carried out at the Laboratory of Clinical Immunology of "Faculdade de Ciências Farmacêuticas de Araraquara" - Universidade Estadual Paulista, Araraquara, SP, Brazil. Cell viability was evaluated by trypan blue exclusion test, and only the cell suspensions that showed $95 \%$ of viability were employed in the studies. 
Animals

Seventy-six male Swiss mice weighing 18 to $25 \mathrm{~g}$ were supplied by the Faculdade de Ciências Farmacêuticas, Universidade Estadual Paulista, Araraquara, SP, Brazil. They were maintained in polycarbonate boxes at $23 \pm$ $2{ }^{\circ} \mathrm{C}, 56 \pm 2 \%$ humidity, $10-18$ cycles/h and a $12 \mathrm{~h}$ light/ dark cycle, with water and food available ad libitum.

In vitro and in vivo assays from mice bearing EAT

Animals were sacrificed five days after tumour transplantation, considering as pure culture those containing $95 \%$ of tumour cells, without significantly inflammatory cells influx. ${ }^{14}$

Cell suspensions were collected in an sterile conic tube (Corning Inc.) and were then centrifuged with 15 parts of $\mathrm{NH}_{4} \mathrm{Cl} 0.17 \mathrm{~mol} \mathrm{~L}^{-1}$ followed by phosphate-buffered saline (PBS), $\mathrm{pH} \mathrm{7.2,} \mathrm{for} 5 \mathrm{~min}$ at $2000 \mathrm{rpm}$ and $25^{\circ} \mathrm{C} .{ }^{15}$ Cell concentration was adjusted in RPMI medium (Sigma), using a Neubauer haemocytometer (Boeco) and Trypan blue solution. For in vitro assays, $1.0 \mathrm{~mL}$ of RPMI-1640Complete, RPMI-1640-C (containing 5\% fetal calf serum, mercaptoethanol, penicillin and streptomycin) was added to the cells, adjusting the concentration to $1 \times 10^{6} \mathrm{cell} /$ $\mathrm{mL} .{ }^{16}$ For in vivo assays $1.0 \mathrm{~mL}$ of phosphate-buffered saline (PBS), pH 7.2 was employed, adjusting the concentration to $1 \times 10^{3}$ cell $/ \mathrm{mL}^{14}$

Assessment of citotoxicity using MTT assay for EAT cells

$100.0 \mu \mathrm{L}$ samples of tumour peritoneal cell suspension $\left(1 \times 10^{6} \mathrm{cell} / \mathrm{mL}\right.$, adjusted in RPMI-1640-C), obtained from 10 EAT-bearing mice, were added to each well of a 96well tissue culture plate (Corning) containing $100.0 \mu \mathrm{L}$ of the compounds (1), (2) and cis-DDP in different concentrations (between 100.0 and $5.0 \mu \mathrm{mol} \mathrm{L}^{-1}$ ) or RPMI 1640 -Complete medium with $0.3 \%$ of dimethylsulphoxyde (DMSO) or only RPMI 1640-Complete as cell control of viability, using the Mossman assay. ${ }^{17}$ The effects of the compounds on the cells were determined $48 \mathrm{~h}$ after culture incubation.

Then, supernatants were removed and $100.0 \mu \mathrm{L}$ of solution of [3-(4,5-dimethylthiazol-2-yl)-2,4-dipheniltetrazolium bromide] (MTT) were added to each well containing the samples. MTT assay was performed and the plates were incubated for $3 \mathrm{~h}$. Then, absorbances were measured and the citotoxic midpoint value, the concentration of chemical agent needed to reduce the spectrophotometric absorbance to $50 \%$, was determined by linear regression analysis with $95 \%$ of confidence limits. The $\mathrm{IC}_{50}$ was defined as the average result of three independent experiments through the equation of graphic line obtained (Microcal Origin 5.0 $0^{\mathrm{TM}}$ ).

\section{In vivo assays}

Healthy male Swiss mice were divided in five groups each one containing 10 animals. They were inoculated intraperitoneally (i.p.) with cell suspension at $1 \times 10^{3}$ cells $\mathrm{mL}^{-1}$ of PBS. After 3 days of tumour development, the compounds $\left[\{\mathrm{Pd}(\mathrm{dmba})\}_{2}(\mu-\mathrm{NCS})_{2}\right](\mathbf{1}),[\mathrm{Pd}(\mathrm{dmba})$ (NCS)(dppp)] (2) and cis-DDP were inoculated, according to literature methods. ${ }^{18}$ Groups were named according to the compounds inoculated:

Group 1 or G1: cis-DDP (1 mL, i.p., $\left.10 \mathrm{mg} \mathrm{kg}^{-1}\right)$; Group 2 or G2: [Pd(dmba)(NCS)(dppp)] (1 mL, i.p., $\left.1 \mathrm{mmol} \mathrm{L}^{-1}\right)$; Group 3 or G3: [ $\left.\{\mathrm{Pd}(\mathrm{dmba})\}_{2}(\mu-\mathrm{NCS})_{2}\right](1 \mathrm{~mL}$, i.p., $1 \mathrm{mmol}$ $\mathrm{L}^{-1}$ ); Group 4 or G4: Vehicle control (1mL, i.p., DMSO $0.3 \%$ ); Group 5 or G5: Tumour control (1mL, i.p., PBS).

\section{EAT cells score}

Six animals of each group $(n=12)$ were sacrificed six days after the inoculation with the complexes, i.e., on the ninth day of tumour development. ${ }^{14}$ Determination of the total number of EAT cells was carried out in a Neubauer haemocytometer (Boeco). Differentiation of cells was made by May-Grünwald Giemsa (Reagen) with subsequent observation in an optical microscope under immersion lens $(100 \mathrm{X}) .^{18}$

\section{Cell viability by trypan blue exclusion}

$100.0 \mu \mathrm{L}$ samples of the cell suspension were added to $100.0 \mu \mathrm{L}$ of Trypan blue solution $(1: 10)$ and the samples were dropped into glass sheets and observed in a microscope under 40X lens. We have considered dead the cells which absorbed Trypan blue solution.

\section{Spreading of macrophages}

The spreading of peritoneal macrophages from tumour bearing mice was assessed according to the technique adapted from Rabinovich et al. (1977).$^{19}$ Briefly, aliquots of $200.0 \mu \mathrm{L}$ of peritoneal cell suspensions were placed over glass cover slips (Corning Inc.) and incubated for 15 $\min$ at $37^{\circ} \mathrm{C}$. The non-adherent cells were removed by washing with PBS and the adherent cells were incubated in RPMI-C culture medium, at $37^{\circ} \mathrm{C}$, in a humidified chamber containing $7.5 \%$ of $\mathrm{CO}_{2}$ (Forma Scientific). Subsequently, the medium was removed and the cells were 
fixed with 2.5\% glutaraldehyde (Sigma Chemical Co.) and examined under an optical microscope to determine the percentage of spread cells.

\section{Nitric oxide assay}

Nitric oxide (NO) measurements were made in the mice serum after conversion of $\mathrm{NO}_{3}{ }^{-}$to $\mathrm{NO}_{2}{ }^{-}$by bacterial nitrate reductase. ${ }^{20} 100.0 \mu \mathrm{L}$ of mice serum samples from all test groups were incubated at room temperature in 83.0 $\mu \mathrm{L}$ of Milli-Q water, $15.0 \mathrm{~mL}$ of NADPH (reduced dinucleotide adenine $\beta$-nicotinamide phosphate $-0.5 \mathrm{mg}$ $\left.\mathrm{mL}^{-1}\right)$ and $2.0 \mathrm{~mL}$ of nitrate reductase $\left(5.0 \mathrm{U} \mathrm{mL}^{-1} \mathrm{NADPH}\right.$ reductase) for $2 \mathrm{~h}$. Later, nitrite concentrations were indirectly measured by a quantitative colorimetric assay using Griess reagent system: $50.0 \mu \mathrm{L}$ aliquots of serum were added to $50.0 \mu \mathrm{L}$ of Griess reagent $[1 \%$ sulphanilamide (Merck), 0.1\% naphthylethylenediamine (Merck) and 3\% $\mathrm{H}_{3} \mathrm{PO}_{4}$ (Mallinckrodt)], incubated at room-temperature for $10 \mathrm{~min}$., and the absorbance was measured at $540 \mathrm{~nm}$ in an Elisa reader (Multiskan Ascent Labsystems). Samples in quadruplicate were assayed in four experiments and reported as $\mu$ mols NO / 100.0 $\mu \mathrm{L}$ of serum $\pm \mathrm{SD}$ quantified from the standard curve.

\section{$T N F-\alpha$ bioassay}

L929 mouse tumour cells were used to measure TNFa levels in mice serum. Killing of L929 mouse tumour cells was used to measure the citotoxicity of soluble factor(s) present in the serum. ${ }^{21}$ Briefly, L929 cells were seeded in RPMI-1640-Complete medium at $4 \times 10^{4}$ cells per well in 96-well microlitre plates (Corning) and incubated overnight at $37{ }^{\circ} \mathrm{C}$ in an atmosphere of air/7.5\% $\mathrm{CO}_{2} .100 \mu \mathrm{L}$ of serum samples previously obtained were added, or serum of normal mice, or cells only, as control, plus the same volume of medium containing $1.0 \mathrm{mg}$ Actinomycin $\mathrm{D} \mathrm{mL} \mathrm{mL}^{-1}$ in triplicate. The next day, cell survival was assessed fixing and staining the cells with crystal violet $(0.2 \%$ in $20 \%$ methanol $)$, dissolving the stained cells with $0.1 \mathrm{~mL} \mathrm{1 \%} \mathrm{SDS} \mathrm{(sodium} \mathrm{dodecyl}$ sulphate) (v/v) per well and reading the absorbance of each well at $490 \mathrm{~nm}$ with an Elisa reader (Multiskan Ascent Labsystems). TNF- $\alpha$ units were calculated using a standard curve obtained with recombinant TNF- $\alpha$ constructed for each test run. The criterion employed in this bioassay is that fifty percent of L929 cells death corresponds to one unit of TNF- $\alpha$, approximately one picogram of recombinant TNF- $\alpha .^{22}$ In order to confirm the presence of TNF- $\alpha$ in the culture supernatants, these preparations were previously incubated with rabbit anti-r
TNF- $\alpha$ immune serum, and the test samples were added to L929.

\section{Analysis of the effect of compounds on mice survival}

The mean survival time (MST) of each group containing 6 mice was monitored for 90 days by recording the mortality daily. Based on the values of MST found we calculated the increase in life span (ILS). These parameters were calculated ${ }^{23}$ according to the following equations: $\mathrm{MST}=[($ Day of first death + day of last death $) /$ $2]$ ILS $(\%)=\{[(\mathrm{MST}$ of the treated group/MST of the control group) -1$] \times 100\}$.

\section{Statistical analysis}

Results are representative of three independent experiments and they are presented as Average Values \pm Standard Deviation from quadruplicate observations. Data were statistically analyzed by the variance test in ANOVA and by the Tukey-Kramer post-test, using significance level $\mathrm{p}<0.05$, in the Graph Instat $\mathrm{Pad}^{\mathrm{TM}}$ software.

\section{Results and Discussion}

\section{IR spectra}

Treatment of the thiocyanate-bridged dimer $[\{\operatorname{Pd}(N, C$ dmba $\left.)\}_{2}(\mu-\mathrm{NCS})_{2}\right]$ (1) with dppp gave $[\operatorname{Pd}(C$-dmba $)$ (NCS)(dppp)] (2), in which the diphosphine behaves as a chelating ligand. The IR spectrum of (2) showed $v_{\mathrm{CN}}, v_{\mathrm{CS}}$ and $\delta_{\mathrm{NCS}}$ bands at 2048, 840 and $440 \mathrm{~cm}^{-1}$, respectively, characteristic of a terminal $N$-thiocyanate group, together with the $v_{\mathrm{P}-\mathrm{C}}$ and $\delta\left(\mathrm{C}-\mathrm{P}-\mathrm{C}_{\mathrm{ar}}\right)$ bands at 696 and $1096 \mathrm{~cm}^{-1}$, respectively, characteristic of the diphosphine coordinated to $\mathrm{Pd}$.

These characteristics indicate that compound (2) has the $\mathrm{N}$-coordination of thiocyanate. Taking into account that the coordination geometry around the $\mathrm{Pd}$ atom is square planar, it is suggested that two phosphorus atoms of the phosphine ligand and one carbon atom of dmba, leaving the nitrogen atom of dmba uncoordinated, occupy the three remaining coordination sites. Thus, the compound may be formulated as $[\mathrm{Pd}(C$-dmba)(NCS)(dppp)] (2).

\section{Biological activities}

Ehrlich ascites tumour (EAT) has been used for evaluating both the citotoxic properties of many classes of substances and the influence of substances in immune response. ${ }^{16,24,25}$ Since cis-diamminedichloroplatinum(II) 
(cis-DDP) emerged as the mostly employed antitumour metal-drug, ${ }^{9}$ many novel complexes containing metals of platinum group are being investigated.

Some cyclopalladated complexes ${ }^{26}$ of the type $[\mathrm{Pd}(\mathrm{C}-$ $\mathrm{N})(\mathrm{X})(\mathrm{L})]$, where $\mathrm{C}-\mathrm{N}$ is an aromatic or aliphatic amine coordinated via $\mathrm{C}$ and $\mathrm{N}$ atoms to $\mathrm{Pd}$; $\mathrm{L}=$ nitrogen ligand; $\mathrm{X}=$ chloride or acetate, have shown to be citotoxic towards seven tumour lines ${ }^{27}$, e.g., $[\mathrm{Pd}(\mathrm{dmba})(\mathrm{Cl})(\mathrm{py})] ; \mathrm{dmba}=$ $N, N$ '-dimethylbenzylamine and py $=$ pyridine. ${ }^{26}$ Cyclopalladated complexes containing thiosemicarbazones ligands have also shown antitumour properties when coordinated to palladium atoms. ${ }^{27,28}$

In the MTT assay, ${ }^{17}$ the compound $\left[\{\operatorname{Pd}(N, C \text {-dmba })\}_{2}\right.$ $\left.(\mu-\mathrm{NCS})_{2}\right](1)$ has not shown a considerable activity when compared to the citotoxic behaviour of the complex $[\operatorname{Pd}(C$ dmba)(NCS)(dppp)] (2) as presented in Figure 2. So, we have verified that complex (2) showed lower $\mathrm{IC}_{50}$ value $\left(5.29 \pm 3.89 \mu \mathrm{mol} \mathrm{L}^{-1}\right)$ than those values of cis-DDP (33.77 \pm 2.29$)$ and (1) (47.86 \pm 4.32$)$. These results suggest that structural differences between compounds (1) and (2), such as the number of metal centres and the presence of diphenylphosphine in (2) have influenced their citotoxic effects towards EAT cells in vitro. DMSO has the ability to suppress the growth of Ehrlich carcinoma in the solid form. ${ }^{29}$ In this study the vehicle, DMSO $0.3 \%$ diluted in RPMIComplete medium, was not toxic to EAT cells in vitro (99\% of cell viability, data not shown).

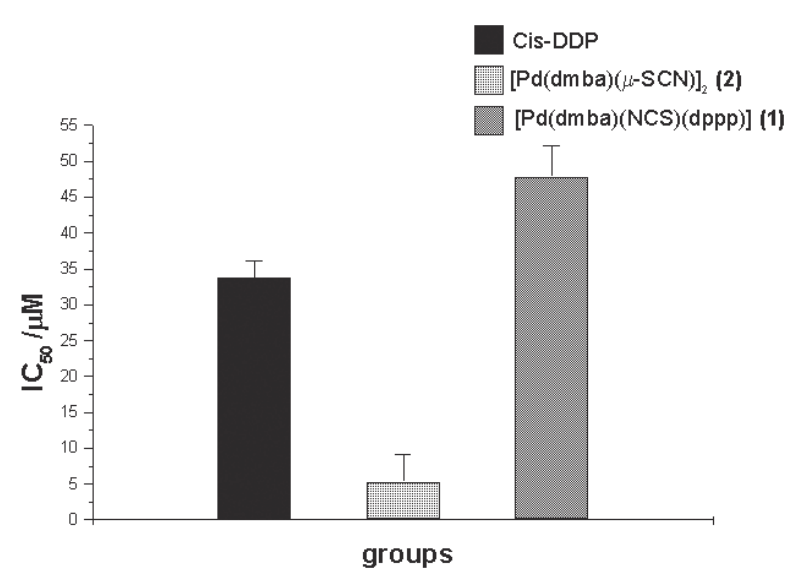

Figure 2. $\mathrm{IC}_{50}$ values $\left(\mathrm{mmol} \mathrm{L}^{-1}\right)$ for compounds, determined by concentration versus cell viability, assay in vitro after $48 \mathrm{~h}$ exposition $-1 \times 10^{6}$ cells $\mathrm{mL}^{-1} ; n=10$ mice.

Besides the tests in vitro, in this study we have performed tests in vivo, evaluating the inflammatory response of the peritoneal cavity of EAT-bearing mice, inoculated intraperitoneally with solutions of compounds (1), (2) and cis-DDP as standard drug.

As reported in the literature, ${ }^{14}$ it has been verified that the inoculation of $1 \times 10^{3}$ cells $\mathrm{mL}^{-1}$ maintained the tumour growth unchanged till the ninth day. During this time the number of polimorphonuclear (PMN) and mononuclear $(\mathrm{MN})$ cells in the cavity was very low. It was observed that the tumour cells did not induce a significant influx of inflammatory cells in this period. Taking into consideration that the spreading due to tumour inoculation occurs in the three first days after inoculation but not later on (nine days), the spreading verified could be due to the action of the compounds. Based on all information above, the complex solutions were injected three days after tumour transplantation, taken as day zero, and the animals were sacrificed on the ninth day of tumour development.

The intensity of the inflammatory reaction evoked by tumour cells is of fundamental importance in the evolution of tumour growth. In clinical pathology, tumours presenting an intense inflammatory infiltrate are considered to have a good prognostic. ${ }^{14}$

Organopalladated solutions of (1) and (2) were responsible for a significant increase of inflammatory influx of macrophages (Figure 3). Cis-DDP and (2) showed values equal to $58.28 \% \pm 7.52(\mathrm{p}<0.001)$ and $36.71 \% \pm 13.2$, respectively, both different from that of tumour control group. However, compound (1) has not showed a statistically significant behaviour, $32.85 \% \pm 3.97$.

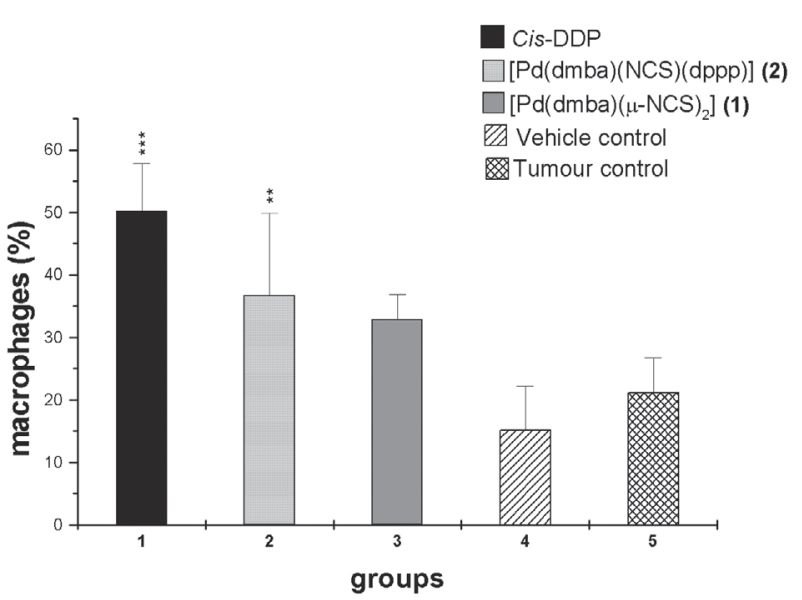

Figure 3. Influence of compounds on the percentage of macrophages in the peritoneal exsudate. The values are represented as mean $\pm \mathrm{SD}$. $* * * \mathrm{p}<0.001$, significantly different of Tumour control group.

According to other report, PMN citotoxic activity in vitro against EAT is significantly high in Swiss mice. The data indicate that PMN acts against EAT controlling tumour development in vivo. ${ }^{30}$

Table 1 shows better performance of complex (2) when compared to (1) and similar to cis-DDP. Polimorphonuclear cells determination suggests that cis-DDP and complex (2) have promoted local inflammatory influx of PMN cells of $22.5 \pm 4.39$ and $38.43 \% \pm 11.7$, respectively 
( $p<0.001$, significantly different of tumour control group), and complex (1) did not cause the same effect in peritoneal cavity $(9.57 \% \pm 3.36)$. The tumour cell percentage has showed equivalent results for cis-DDP $(27.14 \% \pm 4.10)$ and complex (2) $(24.86 \% \pm 4.26)$, while (1) showed a higher value $57.57 \pm 5.22$, demonstrating lower citotoxicity in vivo. The percentage of cell death observed in all groups ranged from $18.75 \pm 4.85$ to $26.25 \pm 4.78$, that is, the difference is statistically non-significant ( $p>0.05$ ).

Activated macrophages present a large number of morphologic, functional, and metabolic differences from resting cells. They are bigger and display pronounced ruffling of the plasma membrane, and increased capacity for adherence and spreading on surfaces, increased formation of pseudopods, and increased number of picnotic vesicles, as well as functional differences. ${ }^{31}$ The results obtained for spreading macrophages have shown that complex (1) presents an expressive value of $62.0 \% \pm$ 22.81 , different from that found in the tumour control group and similar to cis-DDP value of $78.4 \% \pm 16.82$ $(\mathrm{p}<0.001)$, while complex (2) did not present the same effect: $37.4 \% \pm 11.78$.

Our research group has demonstrated that organopalladated compounds containing diphenylphosphine ligands have activated macrophages in vitro ${ }^{32}$ by the immunological activation, in vitro, determining the $\mathrm{H}_{2} \mathrm{O}_{2}$ released in cultures of peritoneal macrophage cells from Swiss mice in the presence of organopalladated compounds of the type $[\mathrm{Pd}(\mathrm{dmba})(\mathrm{X})(\mathrm{dppp})], \mathrm{dmba}=N, N$ dimethylbenzylamine, $\mathrm{dppp}=$ 1,3-bis(diphenylphosphine)propane, $\mathrm{X}=\mathrm{Cl}, \mathrm{N}_{3}, \mathrm{NCO}$, NCS. An excellent activation of macrophages by the $[\mathrm{Pd}(\mathrm{dmba})(\mathrm{X})(\mathrm{dppp})]$ compounds was observed and the influence of the $\mathrm{X}$ ligand on the immune response could be verified.

Activated macrophages secrete several substances that are directly involved in tumour cell killing, i.e., tumour necrosis factor (TNF) and nitric oxide (NO). Taken together, TNF and NO are considered as the most important mediators directly involved in tumour cell killing. ${ }^{5}$
NO is formed in activated phagocytes as a product of the conversion of $L$-arginine to $L$-citruline by an inducible isoform of nitric oxide synthase. This reaction, like the oxidative burst, involves $\mathrm{O}_{2}$ uptake. Nitrite $\left(\mathrm{NO}_{2}^{-}\right)$and nitrate $\left(\mathrm{NO}_{3}^{-}\right)$are generally believed to be the end products of the macrophage reactive nitrogen intermediates generating system. ${ }^{33}$ Although many other agents are citotoxic to target cells, NO is often found to be the primary mediator of macrophage-induced citotoxicity. ${ }^{34}$

Serum NO release, Figure 4, has showed that macrophages were activated with the three substances, (1), (2) and cis-DDP, presenting similar results: $7.61 \pm 0.68$ for (1); $9.18 \pm 1.06$ for (2) and 7.36 \pm 1.25 , (cis-DDP), $\mathrm{p}<0.001$, significantly different of tumour control group $2.05 \pm 0.47$.

These findings can be considered a good prognostic because the citotoxicity as a result of a substantial NOformation is established to initiate apoptosis, characterized by up-regulation of the tumour suppressor p53, changes in the expression of pro- and anti-apoptotic Bcl-2 family members, cytochrome $\mathrm{c}$ relocation, activation of caspases, chromatin condensation, and DNA fragmentation..$^{35}$

It has been reported that murine macrophages treated with cisplatin acquire enhanced capacity to lyse tumour

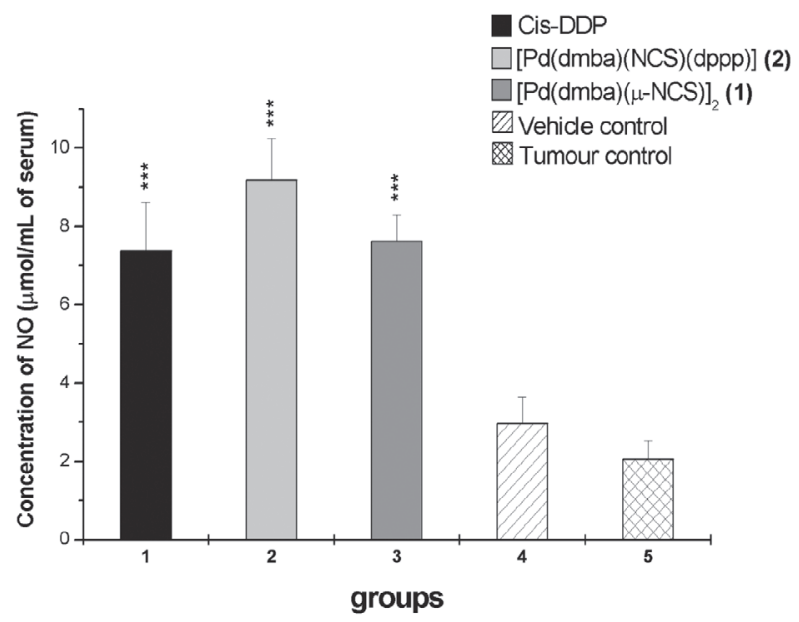

Figure 4. Influence of compounds on NO serum levels. The values are represented as mean $\pm \mathrm{SD}$. $* * * \mathrm{p}<0.001$, significantly different of Tumour control group.

Table 1. Effect of organopalladated compounds in mice bearing Ehrlich ascites tumour

\begin{tabular}{|c|c|c|c|c|c|}
\hline Parameters & {$\left[\left\{\begin{array}{c}\left.\mathrm{Pd}(\mathrm{dmba})\}_{2}(\mu-\mathrm{NCS})_{2}\right] \\
(1)\end{array}\right.\right.$} & $\begin{array}{c}{[\mathrm{Pd}(\mathrm{dmba})(\mathrm{NCS})(\mathrm{dppp})]} \\
(2)\end{array}$ & $\begin{array}{c}\text { cis- }\left[\mathrm{Pt}(\mathrm{Cl})_{2}\left(\mathrm{NH}_{3}\right)_{2}\right] \\
(\text { Cis-DDP })\end{array}$ & Vehicle Control & Tumour control \\
\hline EAT cells $(\%)^{\mathrm{a}}$ & $57.57 \pm 5.22 * * *$ & $24.86 \pm 4.26^{* * *}$ & $27.14 \pm 4.10^{* * *}$ & $81.25 \pm 6.58$ & $73.87 \pm 6.92$ \\
\hline $\operatorname{PMN}(\%)^{\mathrm{b}}$ & $9.57 \pm 3.36$ & $38.43 \pm 11.7^{* * *}$ & $22.57 \pm 4.39 * * *$ & $2.50 \pm 1.52$ & $2.80 \pm 1.92$ \\
\hline Cell death $(\%)^{\mathrm{c}}$ & $26.25 \pm 4.78$ & $18.75 \pm 4.85$ & $22.50 \pm 2.88$ & $25.50 \pm 3.32$ & $25.50 \pm 3.32$ \\
\hline Spread macrophages $(\%)^{\mathrm{d}}$ & $62.0 \pm 22.81^{* * *}$ & $37.40 \pm 11.78$ & $78.40 \pm 16.82 * * *$ & $15.14 \pm 5.55$ & $17.71 \pm 7.06$ \\
\hline
\end{tabular}

${ }^{\mathrm{a}-\mathrm{d}}$ data are reported as MEAN $\pm \mathrm{SD}$ for at least three independent experiments carried out in triplicate. adifferentiate score by Giemsa methods, ${ }^{* * *} \mathrm{p}<0.001$

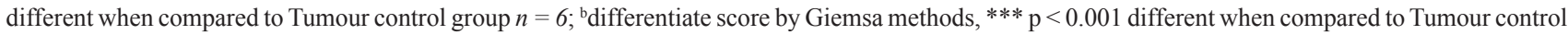
group; $n=6$; ' results obtained by trypan blue methods, $\mathrm{p}>0.05$, similar to Tumour control group $n=6$; ${ }^{\mathrm{d}}$ spreading of macrophages, $* * * \mathrm{p}<0.001$ different when compared to Tumour control group, $n=6$. 
cells in vitro, produce increased amount of interleukin-1 (IL-1) and tumour necrosis factor (TNF), reactive oxygen metabolites (ROI), reactive nitrogen intermediates (RNI), lysozyme and arginase. ${ }^{36}$

Tumour necrosis factor alpha (TNF- $\alpha$ ) is an immunomodulatory cytokine that has exhibited an antitumour activity in a variety of tumour cell lines, including breast cancer cell lines..$^{37}$ On the other hand, it is becoming more evident that many aspects of tumour promotion arise from persistent and unresolving inflammation. Clinically, elevated serum concentrations and increased expression of TNF-alpha are present in various pre-neoplastic and malignant diseases, compared with serum and tissue from healthy individuals. ${ }^{38}$

TNF- $\alpha$ serum levels (Figure 5) in the group treated with $c i s$-DDP have presented $48.45 \pm 3.68 \mathrm{U} \mathrm{mL}^{-1}$, and complex (2) $67.27 \pm 5.89 \mathrm{U} \mathrm{mL}^{-1}(\mathrm{p}<0.001$, significantly different of tumour control, $330.57 \pm 8.12$ ). Complex (1) have presented results similar to those given by the tumour group (318.14 $\left.\pm 14.44 \mathrm{U} \mathrm{mL}^{-1}\right)$.

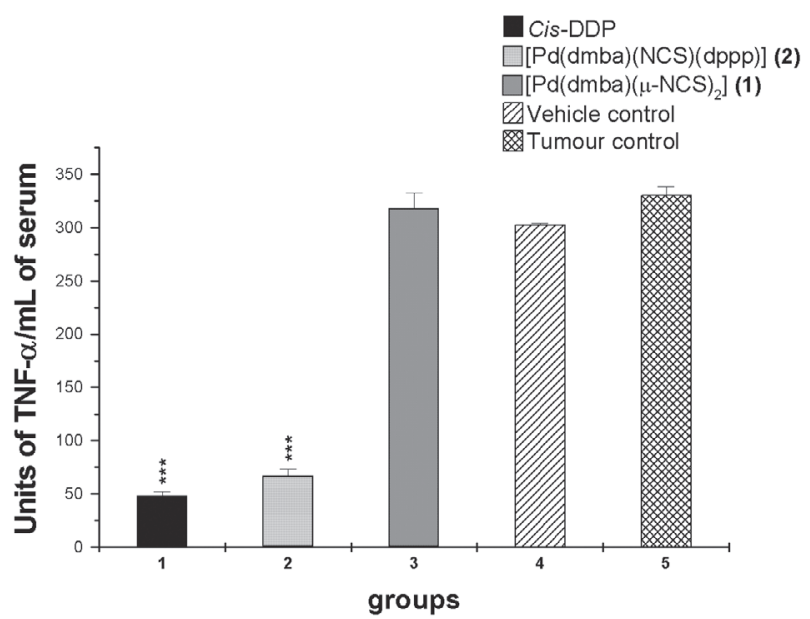

Figure 5. Influence of compounds on serum levels of TNF- $\alpha$. The values means mean \pm SD. $* * * p<0.001$, significantly different of Tumour control group.

The decrease of TNF- $\alpha$ serum levels in the groups treated with compound (1) may be a good prognostic because the TNF over-expression may lead to malignancy as described above. Besides, a potential tumour-promoting effect of TNF$\alpha$ has been demonstrated in study, showing that mice deficient in TNF- $\alpha$ were resistant to skin carcinogenesis. ${ }^{39}$ Other data have demonstrate that over-expression of TNF- increased metastatic activity of tumour lines, ${ }^{40}$ and treatment of mice with TNF- $\alpha$ promoted development of liver metastasis. ${ }^{41}$ In a study involving patients with prostate cancer, the results suggest that TNF-alpha directly correlate with the extent of disease. ${ }^{42}$

Despite described in literature, in this paper mice treated with cis-DDP presented decrease in TNF- $\alpha$ levels. IFN- $\gamma$ is a cytokine that stimulates the synthesis of inducible nitric oxide synthase (iNOS) and the release of NO from macrophages ${ }^{43}$ Based on in vivo and in vitro observations, many anti-tumour mechanisms have been attributed to IFN- $\gamma$ in several tumour lineages, including against breast cancer cells. ${ }^{37,44,45}$

In this paper, the increase in NO concentration was observed concomitantly with the decrease of the TNF- $\alpha$ level. In future, experiments IFN- $\gamma$ determinations deserve to be performed in order to verify its levels in mice treated with the compounds and the correlation with the NO levels.

A reliable criterion for judging the value of any anticancer agent is the increase of life span of animals. ${ }^{23}$ Regarding this point, compound (2) has presented the best performance values, showing mean survival time superior to 90 days, equivalent to more than $100 \%$ of ILS, as with cis-DDP (Table 2).

Table 2. Effect of organopalladated compounds in the mean survival time (MST) and increase in life span (ILS) of the EAT-bearing mice

\begin{tabular}{lcc}
\hline Groups & MST(days) & ILS (\%) \\
\hline G1 & $90^{*}$ & $100^{* * *}$ \\
G2 & $90^{*}$ & $100^{* * *}$ \\
G3 & 36 & 5.88 \\
G4 & 34 & - \\
G5 & 34 & - \\
\hline
\end{tabular}

$\mathrm{n}=6$ mice in each group, $*$ time that the mice were monitored daily, ${ }^{* * *} \mathrm{p}<0.001$ related to Tumour control group; average values. Group 1 or G1: Cis-DDP; Group 2 or G2: [Pd(dmba)(NCS)(dppp)] (2); Group 3 or G3: $\left[\{\mathrm{Pd}(\mathrm{dmba})\}_{2}(\mu-\mathrm{NCS})_{2}\right]$ (1); Group 4 or G4: PBS/DMSO 0,3\% (Vehicle control); Group 5 or G5: PBS (Tumour control).

Conjunction of overall data, mainly those related to the serum NO and TNF- $\alpha$ release, showed that the mononuclear compound $[\mathrm{Pd}(C$-dmba)(NCS)(dppp)] (2) presented a behaviour similar to that of cis-DDP. Organopalladated compounds deserve to be tested with other lines of mammary tumour cells, in vitro and in vivo, according to studies developed with many compounds of palladium(II) to confirm their antitumour properties.

The cyclometallated $\left[\{\mathrm{Pd}(N, C \text {-dmba })\}_{2}(\mu-\mathrm{NCS})_{2}\right](\mathbf{1})$ has presented a good performance promoting inflammatory influx of macrophages and PMN cells to the peritoneal cavity. However, it has not showed high citotoxic activity nor immunomodulatory effects as did $[\mathrm{Pd}(C$-dmba)(NCS)(dppp)] (2), according to the elevated number of EAT cells percentage in the peritoneal cavity and the lower increase in the mice life span.

\section{Conclusions}

Both compounds, $\left[\{\mathrm{Pd}(\mathrm{N}, \mathrm{C} \text {-dmba })\}_{2}(\mu-\mathrm{NCS})_{2}\right](\mathbf{1})$ and $[\operatorname{Pd}(C$-dmba)(NCS)(dppp)] (2), have shown citotoxic potential in vitro and in vivo, increasing the life span of the EAT-bearing mice, but (1) presented a lower citotoxic 
potential when compared to compound (2). Compound (2) has shown an activity similar to that of cis-DDP; this indicates that this compound is promising in the study of antitumour and immunological activity. The presence of dppp in complex (2), along with other structural characteristics, may be responsible for its better performance.

\section{Acknowledgments}

The authors acknowledge the financial support received from CAPES, CNPq and FAPESP.

\section{References}

1. Galli, S.; Labato, M. I.; Joffé, E. B. K.; Carreras, M. C.; Poderoso, J. J.; Cancer Res. 2003, 63, 6370.

2. Stacker, S. A.; Achen, M. G.; Jussila, L.; Baldwin, M. E.; Alitalo, K.; Nature Rev. Cancer 2002, 2, 573.

3. Parkin, D.M.; Pisani, P.; Ferlay, J.; Int. J. Cancer 1999, 80, 827.

4. Dranoff, G.; Nature Rev. Cancer 2004, 4, 11.

5. Klimp, A.H.; De Vries, E.G.E.; Scherphof, G.L.; Daemen, T.; Crit. Rev. Oncol./Hematol. 2002, 44, 143.

6. Kim, C.; Park, E.; Quinn, M.R.; Schuller-Levis, G.; Immunopharmacol. 1996, 34, 89.

7. Kroencke, K. D.; Kolb-Bachofen, V.; Bershick, B.; Burkart, V.; Kolb, H.; Biochem. Biophys. Res. Commun. 1991, 175, 752.

8. Grisham, M. B.; Lancet 1994, 344, 859.

9. Rosenberg, B.; Vancamp, L.; Krigas, T.; Nature 1965, 205, 698.

10. Singh, R. A. K; Sodhi, A.; Biochim. Biophys. Acta 1998, 1405 , 171.

11. Decatris, M.P.; Sundar, S.; O’ Byrne, K.J.; Cancer Treatment Rev. 2004, 4, 53.

12. Higgins, J. D.; Neely, L.; Fricker, S. J.; Inorg. Biochem. 1993, $49,149$.

13. De Lucca Neto, V.A.; Mauro, A.E.; Caires, A.C.F.; Ananias, S.R.; De Almeida, E.T.; Polyhedron 1999, 18, 413.

14. Fecchio, D.; Sirois, P.; Russo, M.; Jancar, S.; Inflammation 1990, 14, 125.

15. Slater, L.M.; Murray, S. L.; Wetzel, M.W.; Wisdom, R.M.; Du Valle, E.M.; J. Clin. Invest. 1982, 70, 1131.

16. Esteves-Souza, A.; Silva, T.M.S.; Alves, C.C.F.; Carvalho, M.G.; Braz-Filho, R.; Echevarria, A.; J. Braz. Chem. Soc. 2002, 13, 838.

17. Mossman, T.; J. Immunol. Methods 1983, 65, 55.

18. Saad-Hossne, R.; Saad-Hossne, W.; Prado, R.G.; Acta Cir. Bras. 2003, 18, 534 .

19. Rabinovitch, M.; Manejias, R.E.; Russo, M.; Abbey, E.E.; Cell. Immunol. 1977, 29, 86.

20. Ahmad, A.; Abdin, M.Z.; Plant Sci. 1999, 43,1.

21. Carswell, E.A.; Old, L.J.; Kassel, R.L.; Green, S.; Fiore, N.; Williamson, B.; Proc. Natl. Acad. Sci. USA 1975, 72, 3666.
22. Carlos, I.Z.; Sgarbi, D.B.; Angluster, J.; Alviano, C.S.; Silva, C.L.; Mycopathologia 1994, 127, 189.

23. Gupta, M.; Mazumder, U.K.; Kumar, R.S.; Kumar, T.S.; Acta Pharmacol. Sin. 2004, 25, 1070.

24. Rajkapoor, B.; Jayakar, B.; Murugesh, N.; Indian J. Pharmacol. 2004, 36, 38.

25. Saad-Hossne, R.; Saad-Hossne, W.; Prado, R. G.; Acta Cir. Bras. 2004, 19, 210 .

26. Caires A.C.F.; Mauro, A.E.; Quim. Nova. 1996, 19, 59.

27. Caires, A.C.F.; De Almeida, E.T.; Mauro, A.E.; Hermely, J.P.; Valentini, S.; Quim. Nova. 1999, 22, 329.

28. Quiroga, A. G.; Ranninnger, C. R.; Coord. Chem. Rev. 2004, 248,119

29. Fahim, F. A.; Esmat, A.Y.; Mady, E. A.; Ibrahim, E.K.; Biol. Res. 2003, 36, 253.

30. Bergami-Santos, P. C.; Mariano, M.; Barbuto, J. A.; Life Sci. 2004, 75, 245.

31. Pinello, K. C.; Fonseca, E.S.M.; Akisue, G.; Silva, A. P.; Oloris, S. C. S.; Sakai, M.; Matsuzaki, P.; Nagamine, M. K.; Neto, J. P.; Daglia, M. L. Z.; Life Sci. 2006, 78, 1287.

32. De Almeida, E. T.; Mauro, A. E.; Santana, A. M.; De Godoy Netto, A. V.; Carlos, I. Z.; Quim. Nova 2005, 28, 405.

33. Moncada, S.; Palmer, R. M. J.; Higgs, E. A.; Pharmacol. Rev. 1991, 43, 109.

34. Tamir, S.; Tannenbaum, S. R.; Biochim. Biophys. Acta 1996, 1288, 31 .

35. Brune, B.; Von Knethen, A.; Sandau, K.B.; Cell Death Differentiation 1999, 6, 969.

36. Shishodia, S.; Sodhi, A.; Shrivastava, A.; Int. J. Immunopharmacol. 1997, 19, 683.

37. Kopreski, M. S.; Lipton, A.; Harvey, H.; Kumar, A.R.; Anticancer Res. 1996, 16, 433.

38. Szlosarek, P.; Charles, KA.; Balkwill, F.R.; Eur. J. Cancer 2006, 42, 745 .

39. Moore, R.J.; Owens, D.M.; Stamp, G.; Nat. Med. 1999, 5, 828.

40. Malik, S.T.A.; Naylor, S.; East, N.; Oliff, A.; Balkwill, F.R.; Eur. J. Cancer 1990, 26, 1031.

41. Orosz, P.; Kruger, A.; Hubbe, M.; Ruschoff, J.; Von Hoegen, P.; Mannel, D.N.; Int. J. Cancer 1995, 60, 867.

42. Michalaki, V.; Syrigos, K.; Charles, P.; Waxman, J.; Br. J. Cancer 2004, 90, 2312.

43. Biringanine, G.; Vray, B.; Vercruysse, V.; Vanhaelen-Fastré, R.; Vanhaelen, M.; Duez, P.; Nitric Oxide 2005, 12, 1.

44. Wadler, S.; Schwartz, E. L.; Cancer Res. 1990, 50, 3473.

45. Ruiz-Ruiz, C.; Munoz-Pinedo, C.; Lopes-Rivas, A.; Cancer Res. 2000, 60, 5673.

Received: August 3, 2006

Web Release Date: November 21, 2007

FAPESP helped in meeting the publication costs of this article. 


\section{Citotoxicity and Immune Response induced by Organopalladium(II) Compounds in Mice bearing Ehrlich Ascites Tumour}

\section{Michelle C. da Rocha, ${ }^{a}$ Anderson M. Santana, ${ }^{b}$ Sandra R. Ananias, ${ }^{a, b}$ Eduardo T. de Almeida,} Antonio E. Mauro, Marisa C. P. Placeres ${ }^{a}$ and Iracilda Z. Carlos ${ }^{*, a}$

${ }^{a}$ Departamento de Análises Clínicas, Faculdade de Ciências Farmacêuticas de Araraquara, Universidade Estadual Paulista, CP 502, 14801-902 Araraquara-SP,Brazil

${ }^{b}$ Departamento de Química Geral e Inorgânica, Instituto de Química de Araraquara, Universidade Estadual Paulista, CP 355, 14801-970 Araraquara-SP,Brazil

${ }^{c}$ Departamento de Ciências Exatas, Universidade Federal de Alfenas, Universidade Federal de Alfenas, 31130-000 Alfenas-MG, Brazil

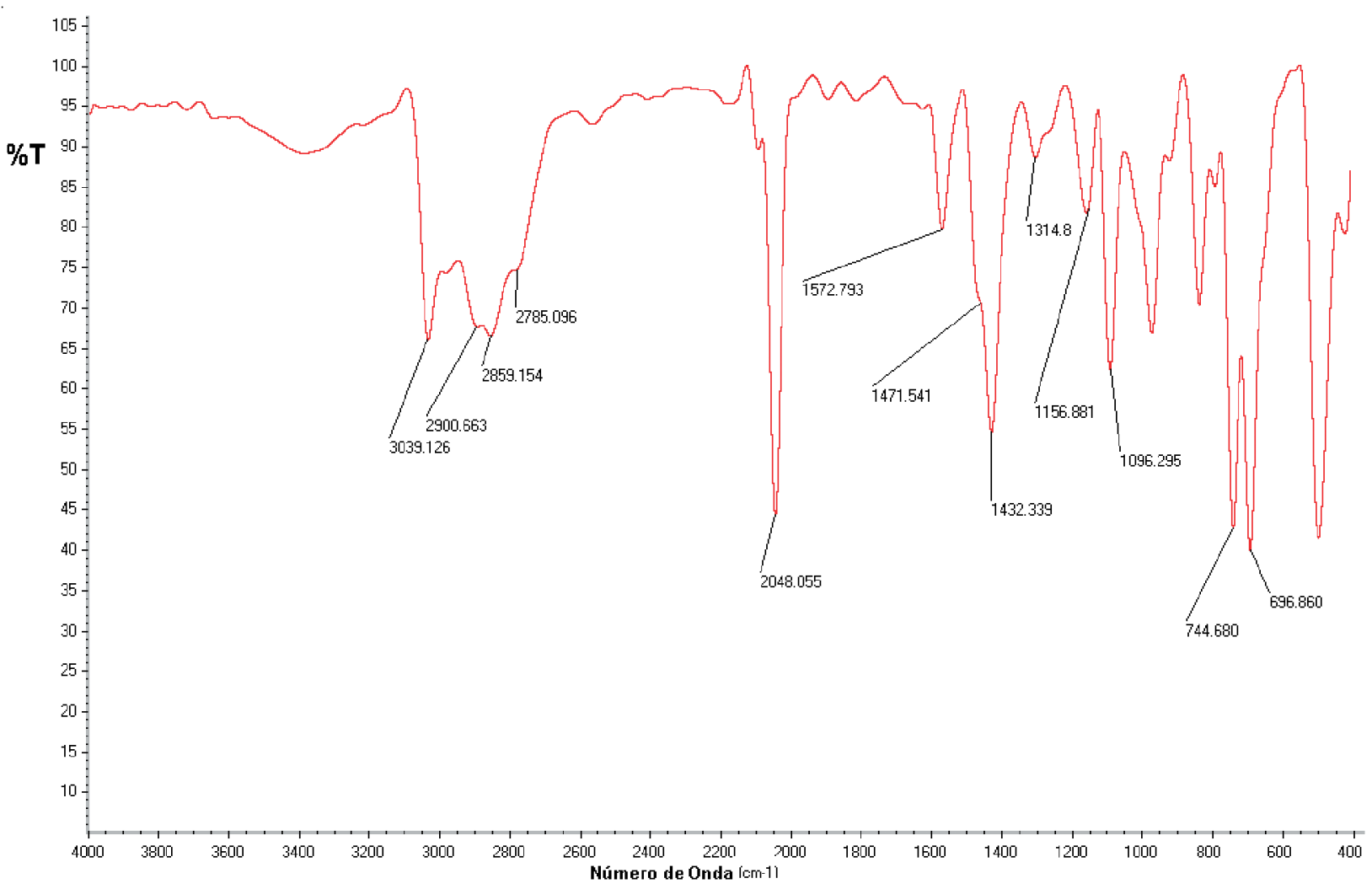

Figure S1. IR spectrum of the compound $[\mathrm{Pd}(\mathrm{C}-\mathrm{dmba})(\mathrm{NCS})(\mathrm{dppp})]$ recorded as $\mathrm{KBr}$ pellets. 